\title{
Peculiarities of the Forestland Taxation System
}

\author{
IRYNA KOSHKALDA ${ }^{1}$, NAZAR STUPEN ${ }^{2}$, TETIANA ANOPRIIENKO ${ }^{3}$, OKSANA STUPEN $^{4}$ \\ ${ }^{1}$ Department of Land Administration and Cadastre, KHARKIV NATIONAL AGRARIAN UNIVERSITY NAMED AFTER \\ V.V. DOKUCHAIEV, UKRAINE, E-mail: irinavit1506@gmail.com \\ ${ }^{2}$ Department of Territorial Cadastre, LVIV POLYTECHNIC NATIONAL UNIVERSITY, UKRAINE, \\ E-mail: nazstupen@gmail.com \\ ${ }^{3}$ Department of Planning of the Territory of Settlements and Construction, KHARKIV NATIONAL AGRARIAN \\ UNIVERSITY NAMED AFTER V.V. DOKUCHAIEV, UKRAINE, E-mail: atatyanav2017@gmail.com \\ ORCID: http://orcid.org/0000-0001-7143-0591 \\ ${ }^{4}$ Department of Land Resources Management, LVIV NATIONAL AGRARIAN UNIVERSITY, UKRAINE, \\ E-mail: oksanashufryn@ukr.net
}

\begin{abstract}
The Forest resources are multifunctional natural resources. It is difficult to overestimate their importance in the life and development of society. Forest resources are an integral part of the ecosystem, and they are a source of energy and food, a protector against the negative effects of nature and human activity. Therefore, it is advisable to determine the value of forest resources and corresponding land plots. The valuation of land plots takes into account different functions of forests, as well as the different types of income that can be derived from forestry activities. Thus, in the process of forestland taxation, a system of taxation is applied, which is based on a comprehensive approach, i.e. the forestland tax is a combination of land tax and rent, determined under the tax legislation.
\end{abstract}

Keywords: Forest; Land plot; Land tax; Tax system; Monetary valuation

JEL Classification: C1, C13, C81, D04, D46, O13, Q15, Q24, R52

Received: March 24, 2021

Accepted: June 12, 2021 


\title{
Peculiaridades del Régimen Fiscal de los Bosques
}

\author{
IRYNA KOSHKALDA ${ }^{1}$, NAZAR STUPEN ${ }^{2}$, TETIANA ANOPRIIENKO ${ }^{3}$, OKSANA STUPEN $^{4}$ \\ ${ }^{1}$ Department of Land Administration and Cadastre, KHARKIV NATIONAL AGRARIAN UNIVERSITY NAMED AFTER \\ V.V. DOKUCHAIEV, UKRAINE, E-mail: irinavit1506@gmail.com \\ ${ }^{2}$ Department of Territorial Cadastre, LVIV POLYTECHNIC NATIONAL UNIVERSITY, UKRAINE, \\ E-mail: nazstupen@gmail.com \\ ${ }^{3}$ Department of Planning of the Territory of Settlements and Construction, KHARKIV NATIONAL AGRARIAN \\ UNIVERSITY NAMED AFTER V.V. DOKUCHAIEV, UKRAINE, E-mail: atatyanav2017@gmail.com \\ ORCID: http://orcid.org/0000-0001-7143-0591 \\ ${ }^{4}$ Department of Land Resources Management, LVIV NATIONAL AGRARIAN UNIVERSITY, UKRAINE, \\ E-mail: oksanashufryn@ukr.net
}

\begin{abstract}
Los recursos forestales son recursos naturales multifuncionales. Es difícil sobrestimar su importancia en la vida y el desarrollo de la sociedad. Los recursos forestales son una parte integral del ecosistema, y son una fuente de energía y alimentos, un protector contra los efectos negativos de la naturaleza y la actividad humana. Por lo tanto, es aconsejable determinar el valor de los recursos forestales y de las parcelas correspondientes. La valoración de las parcelas tiene en cuenta las diferentes funciones de los bosques, así como los diferentes tipos de ingresos que pueden derivarse de las actividades forestales. Así, en el proceso de tributación de las parcelas forestales, se aplica un sistema de imposición que se basa en un enfoque integral, es decir, el impuesto sobre las parcelas forestales es una combinación del impuesto sobre la tierra y la renta, determinada en virtud de la legislación fiscal.
\end{abstract}

Palabras claves: Bosque; Parcela; Impuesto sobre el suelo; Sistema fiscal; Valoración monetaria

Clasificación JEL: C1, C13, C81, D04, D46, 013, Q15, Q24, R52 


\section{Introduction}

There are different models of land taxation in the world. Three main systems to be determined are as follows: first, the land is an independent object of taxation; second, the complex taxation of land along with the real estate objects located on them; third, the land is subject to multiple taxes.

In independent Ukraine, a combined system of land taxation is introduced, which takes into account categories, the intended land use, its form of ownership and intended use. There are some peculiarities of the taxation of forestland as a valuable natural resource of the country. The current practice of taxation of the land plots is based on the data of the State Land Cadaster, including the results of the regulatory monetary valuation of the land. According to the land legislation rules regarding the frequency and obligation of carrying out of the normative monetary valuation (NMV) of non-agricultural lands located within and outside settlements, it is advisable to apply the differentiation of land tax rates for forestland plots, taking into account the peculiarities of forest resources.

The rational use of land resources is a strategic issue for the development of each country. The relevance of the use of the resource potential in agriculture and forestry is the priority importance, taxation context included iError! No se encuentra el origen de la referencia., 2, 3, 4, 5, 6, 7, 8, 9, 10, 11. Much attention is being paid worldwide to forestland management, including the FAO, as far as for many countries forest resources are one of the sources of food security 12, 13, 14, 15.

The application of different models and systems of taxation is based on the use of different approaches chosen by each country to solve various tasks, including social and economic development of society 16 . When taxing objects, different taxable amounts are used, different tax rates are set, etc. 17 .

The most widely applied practice in the world is the system of complex taxation of land plots along with the real estate objects located on them. This system is effectively implemented in Spain, Portugal, the United States, Canada, and several other developed countries. In this case, the tax rates may be the same for the land plot along with the real estate or different for the land and real estate on it. The work "Assessing the Theory and Practice of Land Value Taxation" by F. Dye Richard, and W. England Richard gives an case study for the effective application of such a system in Pennsylvania 18. Some countries use the market value of land as a taxable amount 19.

It is worth noting that, regardless of the model chosen, each country's taxation system is quite complex. At the same time, many countries use tax incentives. Thus, using information resources, the Texas A\&M Forest Service provides ongoing explanatory work on forest resource management, taxation, and benefits to landowners 20, 21, 22.

\section{Methodology}

The study of the subject and the object of the research was carried out using the method of analysis and synthesis, which revealed the drawbacks of the legislative regulation of the processes of the taxation of real estate objects, including the plots of land.

Using the method of interpretation allowed generalizing approaches to the state regulation of the taxation of forestland based on the indicators of the normative monetary valuation of land.

The calculation and constructive method proved the relevance of the revision of the current legislation and the introduction of differentiation of land tax rates for forestland.

The experiment was conducted for adjacent one-hectare forestry areas, one within the settlement and the other one outside it for the category of operational forests and for the category of forests used for the conservation and the use of lands of the nature reserve fund where the main felling is prohibited. 
Using the comparison method has allowed establishing significant differences between the results of valuation and tax rates for the areas under consideration, to substantiate the need to create and implement a single effective model of the taxation of forestland.

To achieve substantiated positive economic results for the development of any industry, it is advisable to use economic and mathematical modeling to solve specific problems. Therefore, to improve the system of the taxation of forestland for the application of international experience of the taxation of real estate, including land, the method of economic and mathematical modeling was used, which allows the use of the combined system of taxation.

Theoretical rethinking and generalization of the results of the study, the formation of conclusions was carried out using the abstract-logical method.

\section{Results And Discussion}

The legislation of Ukraine stipulates that the NMV of the settlement lands should be carried out held every 5-7 years 23 according to the method of the NMV of the settlement lands 24 , and the procedure of the NMV of the residential lands 25, while non-agricultural lands located outside residential areas - at least once every 7-10 years according to the method of NMV of non-agricultural lands (except for settlement lands) 26, and the order of norms and monetary valuation of nonagricultural lands (excluding settlement lands) 27.

When calculating the NMV of forestland plots located within settlements, indicators of the level of development and arrangement of the territory of these settlements are used, which are factored into the average (base) value of one square meter, regional factors of its location, indicators of the level of urban construction value of the territory, local factors of location of the land, taking into account its functional use:

- for forestry and related services (09.01);

- for other forestry purposes (09.02);

- for 09.01-09.02 and the conservation and use of lands of the nature reserve fund (09.03).

When calculating the normative monetary valuation of forestland plots located outside the settlements, the normative rates of rental income per square meter of forestland, capitalization time frame, coefficients including the location of land, type of the land use, land plot location on the lands intended for nature-oriented, wellness, recreational, historical, and cultural purposes (if such status is available), and the coefficient of indexation of the NMV of land.

For example, forestland is located partly within the settlement and partly outside (Fig 1, Table 1).

Forest category is operational forests.

Following the Tax Code of Ukraine 28 the land tax rate for forestlands, which NMV has been conducted is set at the level of $0.1 \%$ of their NMV, and for the lands, which NMV has not been conducted is $0.1 \%$ of the NMV of arable land in the region.

Thus, the use of the same interest rate of the land tax, however, established by the regulatory monetary valuations of different types of land (forest or agricultural (arable) land) affects the amount of land tax, while it changes several times. Besides, the location of forestlands, namely their location within or outside the settlement, will also have a significant impact on the amount of the land tax.

The indicators of the NMV and the land tax for the category of forests used for the conservation and use of the lands of the nature reserve fund where the main felling is prohibited, are a bit different. For example, consider such forestland located partly within the settlement and partly outside the margins (Table 2).

Analyzing the results of the calculations in tables 1 and 2, we can draw the following conclusions:

1. the norm of the Tax Code of Ukraine 29 does not comply with the provisions of the land legislation, and needs clarification; 
2. in the process of the NMV of forestlands located within and outside the settlement, the use of different baseline data (regulated by current methods 24,26 ) results in significant differences in the size of the regulatory monetary valuation of such lands, which further affects the amount of the land tax.

Figure 1 The location of the plots of land

$\leftarrow C \circ$ map.land.gov.ua $\quad$ Public cadastral map of Ukraine
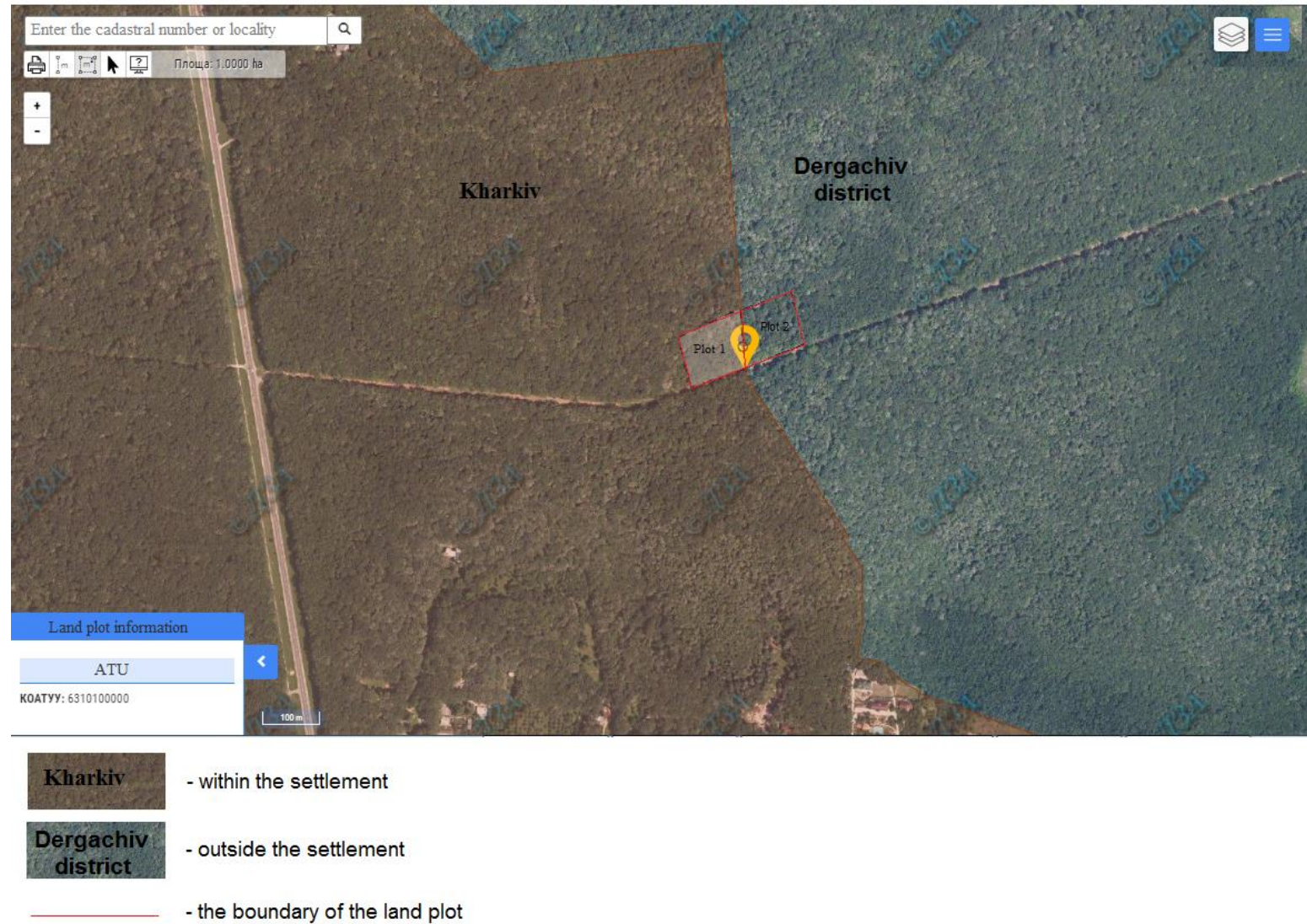

Over the last decade, the norms of land tax legislation have changed essentially several times. Thus, the rates of land tax for forestlands, which NMV has been carried out, made $0.3 \%$ of their NMV, taking into account the tax benefits of such lands; for forest lands, which NMV has not been carried out - up to $5 \%$ of the NMV of arable land in the region; and for forestlands, which NMV has been carried out $-0.1 \%$ of their NMV and $0.1 \%$ of NMV of arable land in the region - for forest lands, which NMV has not been carried out.

Because land in agriculture and forestry is not only a spatial basis, but also the main means of production, it is advisable to set rates of land tax to reflect this fact.

The application of NMV data on arable agricultural land may not correspond to the current state of forestland use, so a transition to the indicators related to the forestry production is needed. Such indicators can be norms of losses of forestry production, which are subject to the compensation during the withdrawal of land from forestry 29.

Assumptions 1 . The rates of normative loss of forestry production are formed based on average indicators of the NMV of forestlands, which are increased by 100 times. Concurrently, the forestry production loss rates for the first group of forests are almost twice as high as for the second group 29. Then the average indicators of regulatory monetary valuation of forestland will be 100 times smaller.

Comparing the average data of the normative monetary valuation of arable agricultural land and the NMV of forestland (established under Assumption 1), we can observe their similarity. 
Table 1 Indicators of the normative monetary valuation of forestland and the amount of land tax (for the category of operational forests)

\begin{tabular}{|c|c|c|c|}
\hline № $3 / n$ & Indicator & Plot 1 & Plot 2 \\
\hline 1 & Area, ha & 1,0000 & 1,0000 \\
\hline 2 & Location & Within the settlement & Outside the settlement \\
\hline 3 & NMV of 1 ha of forestland, UAH & 2746600,00 & 15900,00 \\
\hline 4 & $\begin{array}{c}\text { Normative monetary valuation } 1 \text { ha of } \\
\text { arable land in the region., UAH }\end{array}$ & \multicolumn{2}{|c|}{32237,00} \\
\hline 5 & $\begin{array}{l}\text { Rate of land tax for forestlands, which } \\
\text { normative monetary assessment has been } \\
\text { conducted }\end{array}$ & \multicolumn{2}{|c|}{$0,1 \%$ of their NMV } \\
\hline 6 & $\begin{array}{c}\text { Rate of land tax for forestlands, which } \\
\text { normative monetary assessment has not } \\
\text { been conducted }\end{array}$ & \multicolumn{2}{|c|}{$0,1 \%$ of the NMV of arable land in the region. } \\
\hline 7 & $\begin{array}{c}\text { Amount of the land tax for forestland, which } \\
\text { normative monetary assessment has been } \\
\text { conducted }\end{array}$ & 2746,60 & 15,90 \\
\hline 8 & $\begin{array}{l}\text { Amount of the land tax for forestland, which } \\
\text { normative monetary assessment has not } \\
\text { been conducted }\end{array}$ & 32,24 & 32,24 \\
\hline 9 & $\begin{array}{l}\text { The difference in the amount of land tax, } \\
\text { UAH }\end{array}$ & $-2714,36$ & 16,34 \\
\hline
\end{tabular}

Source: formed by the authors

Table 2 Indicators of the normative monetary valuation of forestland and the amount of land tax (for the category of forests used for the conservation and the use of lands of the nature reserve fund where the main felling is prohibited)

\begin{tabular}{|c|c|c|c|}
\hline № 3/ח & Indicator & Plot 1 & Plot 2 \\
\hline 1 & Area, ha & 1,0000 & 1,0000 \\
\hline 2 & Location & Within the settlement & Outside the settlement \\
\hline 3 & NMV of 1 ha of forestland, UAH & 1525900,00 & 52200,00 \\
\hline 4 & $\begin{array}{c}\text { Normative monetary valuation } 1 \text { ha of } \\
\text { arable land in the region., } \mathrm{UAH}\end{array}$ & \multicolumn{2}{|c|}{32237,00} \\
\hline 5 & $\begin{array}{c}\text { Rate of land tax for forestlands, which } \\
\text { normative monetary assessment has been } \\
\text { conducted }\end{array}$ & \multicolumn{2}{|c|}{$0,1 \%$ of NMV } \\
\hline 6 & $\begin{array}{l}\text { Rate of land tax for forestlands, which } \\
\text { normative monetary assessment has not } \\
\text { been conducted }\end{array}$ & \multicolumn{2}{|c|}{$0,1 \%$ of the NMV of arable land in the region. } \\
\hline 7 & $\begin{array}{c}\text { Amount of the land tax for forestland, } \\
\text { which normative monetary assessment has } \\
\text { been conducted }\end{array}$ & 1525,90 & 52,20 \\
\hline 8 & $\begin{array}{c}\text { Amount of the land tax for forestland, } \\
\text { which normative monetary assessment has } \\
\text { not been conducted }\end{array}$ & 32,24 & 32,24 \\
\hline 9 & $\begin{array}{l}\text { The difference in the amount of land tax, } \\
\text { UAH }\end{array}$ & $-1493,66$ & $-19,96$ \\
\hline
\end{tabular}

Source: formed by the authors

Assumption 2. Considering the complexity of the tax system of Ukraine and the effect of the special taxation regime of forestry activities 28 , we consider several rates of land tax for forestland, which NMV has been carried out:

1. $5 \%$ of the NMV of arable land in the region. According to this rate, the average amount of land tax in Ukraine will be $1322.98 \mathrm{UAH} /$ ha per year, the minimum - $1074.60 \mathrm{UAH} /$ ha per year, and the maximum $-1682.30 \mathrm{UAH} /$ ha per year. 
2. $1 \%$ of the NMV of arable land in the region. According to this rate, the average amount of land tax in Ukraine will be $264.60 \mathrm{UAH} /$ ha per year, the minimum - $214.92 \mathrm{UAH} /$ ha per year, and the maximum - $336.46 \mathrm{UAH} /$ ha per year.

3. $0.1 \%$ of the NMV assessment of arable land in the region. According to this rate, the average amount of land tax in Ukraine will be 26.46 UAH / ha for the year, the minimum - 21.49 UAH / ha for the year, and the maximum - $33.45 \mathrm{UAH} /$ ha for the year.

4. 5\% of the NMV of forestland (established under Assumption 1 for the first group of forests). According to this rate, the average amount of land tax in Ukraine will be $962.80 \mathrm{UAH} /$ ha per year, with the minimum of $264.50 \mathrm{UAH} /$ ha per year, and the maximum of $2226.99 \mathrm{UAH} /$ ha per year.

5. $1 \%$ of the NMV of forestland (established under Assumption 1 for the first group of forests). According to this rate, the average amount of land tax in Ukraine will be $192.56 \mathrm{UAH} /$ ha per year, with the minimum of 52.90 UAH / ha per year, and the maximum of $445.40 \mathrm{UAH} /$ ha per year.

6. $0.1 \%$ of the NMV of forestland (established under Assumption 1 for the first group of forests). According to this rate, the average amount of land tax in Ukraine will be $19.26 \mathrm{UAH} /$ ha per year, with the minimum of 5.29 UAH / ha per year, and the maximum of $44.54 \mathrm{UAH}$ / ha per year.

As the land tax revenue is one of the sources of financing land protection measures and increasing its fertility, the land tax rate of $0.1 \%$ of the NMV of forestland or arable land in the region does not correspond with the current economic conditions and thus, it cannot be a single flat rate. The most optimal way is to determine differentiated land tax rates in the range of $0.1 \%$ to $1 \%$ for the first and second groups of forests.

That is, for example, for the first group of forests in the Transcarpathian region the amount of land tax for the first group of forests with a tax rate of $1 \%$ will be $52.90 \mathrm{UAH} /$ ha per year, and for the second group of forests $-31.78 \mathrm{UAH} /$ ha per year. If the area of the farm is 1000 hectares, and 500 hectares of this area are forests of the first group and 500 hectares of forests of the second group, then the total amount of land tax will be 42338,52 UAH per year. Concurrently, when setting a minimum tax rate of $0.1 \%$, the amount of land tax for such a plot will be UAH 4233,85 per year.

Consider, for example, the Kherson region, where according to the table of standards of losses of forestry production, forests are only of the first group, the size of the land tax with a tax rate of $1 \%$ will be 296,99 UAH / ha per year, and for the area of 1000 hectares of a farmland - $296990,00 \mathrm{UAH}$ per year. Applying the minimum tax rate of $0.1 \%$, the amount of land tax for such a plot will be UAH 29699.00 per year.

\section{Conclusion}

The results of the study indicate the relevance of conducting a NMV of forestlands located outside settlements to a further use of these results in setting rates and determining the amount of land tax.

Concerning the above-mentioned, the study showed that the introduction of a single tax rate at the level of $0.1 \%$ of the NMV of land located outside settlements will contribute to the effective implementation of environmental measures, due to the low income from land payments; unlike the tax rate of $1 \%$ of the NMV of such plots. In this case, differentiation of land tax rates for forestland will allow the local authorities to make prudent management decisions and regulate the level of revenues to local budgets to comply with environmental legislation, preserve and improve the country's land and forest resources.

Furthermore, considering the current legislation on the NMV of forestlands located within settlements, it is advisable to apply a land tax rate of $0.1 \%$ of their NMV, which will allow not increasing the tax pressure on such farms. 
1. Koshkalda, I.V., Tyshkovets, V.V., Suska, A.A. (2018). Ecological and economic basis of anti-erosion stability of forest-agrarian landscapes. Journ. Geol. Geograph. Geoecology, 27(3), p. 444-452. (in Ukrainian). doi: https://doi.org/10.21003/ea.V176-08.

2. Popov, A., Koshkalda, I. Kniaz, O., \& Trehub, O. (2019). Land fragmentation of agricultural enterprises in the context of administration of land. Economic Annals - XXI, 176(3-4), p. 80-90. doi: https://doi.org/10.21003/ea.V176-08.

3. Popov, A. (2017). Assessment of land fragmentation of agricultural enterprises in Ukraine. Economic Annals - XXI, 164(3-4), p. 56-60. doi: https://doi.org/10.21003/ea.V164-13.

4. Tikhonova, A., Telegina, Zh., Babanskaya, A., \& Grudneva, A. (2019). Evaluation of the optimal ratio for consumption and income taxes with the use of econometric methods. Economic Annals XXI, 177(5-6), p. 44-52. doi: https://doi.org/10.21003/ea.V177-04.

5. Börner, J., Wunder, S., Wertz-Kanounnikoff, S., Rügnitz Tito, M., Pereira, L., Nascimento, N., (2010). Direct conservation payments in the Brazilian Amazon: Scope and equity implications. Ecological Economics 69 (6), p. 1272-1282. doi: https://doi.org/10.1016/j.ecolecon.2009.11.003.

6. Kosova, T., Slobodyanyuk, N., Polzikova, H., \& Šatanová, A. (2018). Tax gap management: theory and practice. Economic Annals-XXI 174(11-12), p. 22-28. doi: https://doi.org/10.21003/ea.V17404.

7. Puah, Ch.-H., Liew, V. Kh.-S., \& Tang, M. M.-J. (2017).The pass-through effect of interest rate and asymmetric adjustment in Indonesia Economic Annals - XXI, 166(7-8), p. 61-66 doi: https://doi.org/10.21003/ea.V166-12.

8. Lipkova, L., Gress, M., \& Poncarova, A. (2017). Tax systems in the Czech Republic and the Slovak Republic: comparison with an emphasis on income tax Economic Annals - XXI, 165(5-6), p. 47-51. doi: https://doi.org/10.21003/ea.V165-10.

9. Sidorova, E., \& Tikhonova, A. (2017). Assessment of the fiscal effect of the tax reform options until 2019: the case of Russia. Economic Annals - XXI, 164(3-4), p. 45-48. doi: https://doi.org/10.21003/ea.V164-10.

10.Lemishko, O. Tax policy tools used to stimulate agriculture: their implementation and effectiveness. (2017). Economic Annals - XXI 167(9-10), p. 18-22 doi: https://doi.org/10.21003/ea.V167-04.

11.Ludvig A., Rogelja T., Asamer-Handler M., Weiss G., Wilding M., Zivojinovic I. Governance of Social Innovation in Forestry. (2020). Sustainability, 12, 1065. doi:10.3390/su12031065 www.mdpi.com/journal/sustainabilityfile:///C:/Users/ASER/Downloads/sustainability-1201065.pdf.

12.Menzies, N. Forest and land management in imperial China (1994). URL: https://www.palgrave.com/gp/book/9780312102548.

13.Dhanmanjiri Sathe, The Political Economy of Land Acquisition in India doi: 10.1007/978-981-105326-9 URL: https://link.springer.com/book/10.1007/978-981-10-5326-9.

14.Gregersen H. M., Arnold J. E. M., Lundgren A. L., Contreras A. Hermosilla Valuing forests: context, issues and guidelines, 1995 (EFS) FAO FORESTRY PAPER 127. URL: http://www.fao.org/3/v7395e/v7395e00.htm.

15.Hu, X., Gao, L., Ma, C. et al. Land use zoning of Weifang North Plain based on ecological function and geo-environmental suitability. Bull Eng Geol Environ (2020). URL: https://doi.org/10.1007/s10064-019-01706-9.

16.L. M. Malyarets, V. O. Babenko, O. V. Nazarenko, N. I. Ryzhikova. The Modeling of Multi-criteria Assessment Activity in Enterprise Management, Int. J Sup. Chain. Mgt, Vol. 8, No. 4, 2019. Pp. $997-$ 1004.

17.Bird, R., Slack, E. (2003). International Handbook of Land and Property Taxation.UK: Oxford University Press, 320p. URL: https://www.e-elgar.com/shop/international-handbook-of-land-andproperty-taxation. 
18.Richard, F. Dye, Richard, W. England. (2010). Assessing the Theory and Practice of Land Value Taxation. Cambridge: Lincoln Institute of Land Policy, 34 p. URL: https://www.lincolninst.edu/sites/default/files/pubfiles/assessing-theory-practice-land-value-taxation-full_0.pdf.

19.Bird, R. M., Slack, E. (2005). Land and property taxation in 25 countries: a comparative review. CESifo DICE Report, № 3, pp. 34-42. URL: https://core.ac.uk/download/pdf/6631080.pdf.

20.TEXAS A\&M FOREST SERVICE. URL: https://tfsweb.tamu.edu/default.aspx.

21.Darius M. Adams, Richard W. Haynes The Utility of forest sector models in addressing forest policy questions, pp. 545-560. URL: https://link.springer.com/chapter/10.1007\%2F978-1-4020-63091_17, doi: 10.1007/978-1-4020-6309-1_17.

22.Ralph J Alig, Andrew Plantinga Methods for projecting areas of private timberland and forest cover types, pp. 175-227. URL: https://link.springer.com/chapter/10.1007\%2F978-1-4020-63091_5, doi: 10.1007/978-1-4020-6309-1_5.

23.Pro otsinku zemel: Zakon Ukrayiny № 1378-IV vid 11.12.2003r. (On land valuation: Law of Ukraine No. 1378-IV dated December 11, 2003.) URL: http:/zakon5.rada.gov.ua/laws/show/1378-15.

24. Metodyka normatyvnoyi hroshovoiy otsinky zemel naselenykh punktiv: zatv. Postanovoyu Kabinety Ministriv Ukrayiny № 213 vid 23.03.1995r. (zi zminamy na 11.10.2018) (Methodology of normative monetary valuation of settlement lands: approved by the Resolution of the Cabinet of Ministers of Ukraine No. 213 dated 23.03.1995 (with amendments by 11.10.2018)) URL URL: http:/zakon.rada.gov.ua/laws/show/213-95-ח.

25.Poryadok normatyvnoyi hroshovoiy otsinky zemel naselenykh punktiv: zatv. Nakazom M-va agrarnoyi polityky ta prodovolstva Ukrayiny № 489 vid 25.11.2016r. (Procedure for the normative monetary valuation of the settlement lands: approved by the Order of the Ministry of Agricultural Policy and Food of Ukraine No. 489 dated 25.11.2016.) URL: http:/zakon.rada.gov.ua/laws/show/z1647-16.

26. Metodyka normatyvnoyi hroshovoiy otsinky zemel nesilskogospodarskogo pryznachennya (krim zemel naselennykh punktiv): zatv. Postanovoyu Kabinetu Ministriv Ukrayiny № 1278 vid 23.11.2011r. (Methodology of normative monetary valuation of non-agricultural lands (except for settlements): approved by the Resolution of the Cabinet of Ministers of Ukraine No. 1278 dated 23.11.2011.) URL: http:/zakon3.rada.gov.ua/laws/show/1278-2011-п.

27.Poryadok normatyvnoyi hroshovoiy otsinky zemel nesilskogospodarskogo pryznachennya (krim zemel naselennykh punktiv): zatv. Nakazom M-va agrarnoyi polityky ta prodovolstva Ukrayiny № 508 vid 22.08.2013r. (Procedure for normative monetary valuation of non-agricultural lands (except for settlements): approved by the Order of the Ministry of Agricultural Policy and Food of Ukraine No. 508 dated August 22, 2013.) URL: http:/zakon4.rada.gov.ua/laws/show/z1573-13/print1360517383069506.

28.Podatkovy kodeks Ukrayiny (Tax Code of Ukraine.) URL: http:/zakon.rada.gov.ua/laws/show/2755-17?find=1\&text=\%B3\%ED\%E4\%E5\%EA\%F1\#w17.

29.Pro rozmiry ta Poryadok vyznachennya vtrat silskogospodarskogo i lisogospodarskogo vyrobnytstva, yaki pidlyagayut vidshkoduvannyu: Postanova Kabinetu Ministriv Ukrayiny № 1279 vid 17.11.1997r. (On the Amounts and Procedure for Determining the Losses of Agricultural and Forestry Production to be Compensated: Resolution of the Cabinet of Ministers of Ukraine No. 1279 dated 17.11.1997.) URL: https://zakon.rada.gov.ua/laws/show/1279-97-\%D0\%BF. 